\title{
Analysis on the Application of General Semantics in We-Media Communication
}

\author{
Feng Liu \\ College of Publishing, University of Shanghai for Science and Technology, Shanghai, China
}

\section{Email address:}

panda197@163.com

\section{To cite this article:}

Feng Liu. Analysis on the Application of General Semantics in We-Media Communication. Communication and Linguistics Studies. Vol. 3, No. 1, 2017, pp. 1-4. doi: 10.11648/j.cls.20170301.11

Received: April 20, 2017; Accepted: May 19, 2017; Published: June 16, 2017

\begin{abstract}
General semantics is a theory of the relationship between language and life, although has declined, but many theoretical ideas of general semantics still have certain practical significance. The fragmentation characteristics of we-media language bring certain negative effect for mass communication, general semantics advocates language should reflect the objective reality scientifically and accurately, this has certain reference significance to solve the problems of language in we-media communication. But because of the complexity of the theoretical system of general semantics, the feasibility of general semantics should be studied first, take the essence, to its dregs, then apply it in the mass communicate practice creatively.
\end{abstract}

Keywords: General Semantics, We-Media, Fragmentation

\section{Introduction}

General semantics is a branch of semantics, mainly research on the relationship between human language and the objective of life. On the basis of abstract theory of language, general semantics take the scientific and accurate expression of the objective reality very seriously. General semantics once was so advanced in the world, but declined rapidly in the late 1960 s, then should consider whether its theory still has scientific factors and could be used to guide mass communication currently.

We-media has became a typical example of new digital media with a rapid development in recent years, just as the amount of reading has shown a rapid growth in the most representative social networking software in China called We Chat (Figure1). Due to the limitations of propagation characteristics such as the length limit of micro-blog, we-media language formed a distinguishing feature of fragmentation, giving rise to a negative impact on accurate communication while bringing great convenience to the people. This paper will analyze the characteristics of we-media language and research the path of application of general semantics in we-media communication.

\section{The Development and Decline of General Semantics}

General semantics mainly research on the relationship between human language and the objective of life, pursuing the meaning of scientific and accurate language expression. General semanticist think if everyone could act as a scientist in their use of language, it can guarantee the correct transmission of meaning then reduce misunderstanding and disputes between people. General semantics was born in the United States in the 1930s, flourished in the 1950 s but began to decline rapidly in the late 1960 s.

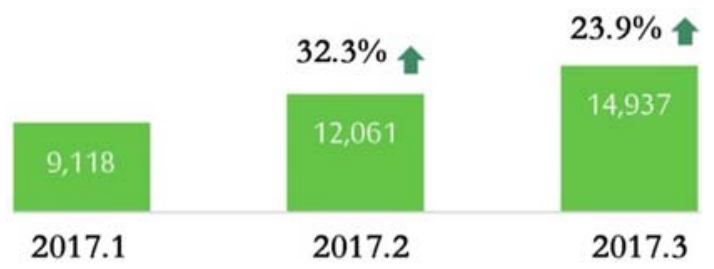

Figure 1. Trends of article reading in WeChat (2017Q1) [1].

Alfred Korzybski published "Science and sanity" with a subtitle of "An Introduction to Non-Aristotelian Systems and 
General Semantics" in 1933 which laid the theoretical foundation of general semantics. Korzybski questioned the logic of language system since Aristotle, he pointed out that Aristotle's logic language only reflected the style and level of the ancient Greeks, but not the universal regulation of human thinking and language. At the same time Korzybski proposed the requirement to change the current structure of the language to a more scientific way which is the original point of the movement of general semantics. Stuart Chase published "The tyranny of words" in 1938 and paid great effort to promote the view of general semantics. After the impetus of the representative scholars and general semantics began to prevail in the 1950s and 1960s in the United States, there were hundreds of university teaching course in general semantics, and its theory was used in quite a lot areas such as news, economic, administration, law of different degree. Finally became a social movement with wide influence which beyond the academic category.

General semantics scholars believe the source of misunderstanding, conflict, disaster is language, which can be recognized from the summary of their linguistic features. Firstly, human language is static while the objective reality is dynamic, language has a certain degree of stability but the world is changing all the time, so Trump in November 9, 2016 is different from Trump in November 1, 2016. Secondly, human language is limited while the actual is infinite, human beings are impossible to describe the objects at all due to the limitations of language. Thirdly, human language is abstract and the world is concrete, when people describe things using abstract language, the listener get an image with a difference [2], namely "the map is not the field, language is not a thing [3]". People will use abstract nouns in the abstract process of reflecting the objective reality and abstract nouns are empty words, so the higher the degree of the abstract concept the danger degree is bigger, which is the reason why language will cause disaster to human society.

In order to solve this problem, scholars of general semantics proposed the semantic analysis, hoping to eliminate the disputes in the process of communication by reforming language. But there were certain relativism color with its theoretical propositions, exaggerated the role of language to the society, ignored the important role of abstraction in human understanding. Due to the discipline system is a mixture of different theories of right or wrong, general semantics declined rapidly in the late 1960s, just as Laib Porter said, traditional general semantics is not suitable for the current situation in the United States and the 1968 world.

Effects of general semantics is very small in China which is determined by the background of that time, Korzybski served as the principal responsible person of League of Nations, Chase advisory committee of president Roosevelt, Hayakawa Ichii was a member of the house of Lords. Many representatives of the general semantics have important political identity, they strived to solve the political problems with their theory. Because general semantics was used by the United States as a tool of cold war, so the theory subjected a boycott in the socialist camp unanimously, there have been only a few works in Hong Kong and Taiwan about general semantics before China's reform and opening-up. Despite the drawbacks, this is not reason to deny that general semantics has a lot of reasonable opinions, the exploration for the establishment of language system which in line with the objective reality is worth learning.

\section{Linguistic Features of We-Media and Its Influence of Communication}

With the development of digital technology, a variety of new media developed rapidly in the world based on Web2.0 platform. In recent years, we-media exhibited a unique attraction and gathered a large number of users, "it refers to the private communicator which sending information to an unspecific majority or a specific individual in a modern, electronic way [4]". According to "the 39th China Internet development status survey report" released by the China Internet Network Information Center (CNNIC), the scale of Internet users reached 0.731 billion in China as of 2016 December, mobile phone users reached 0.695 billion [5], and we-media user also got a tremendous growth (Figure 2).

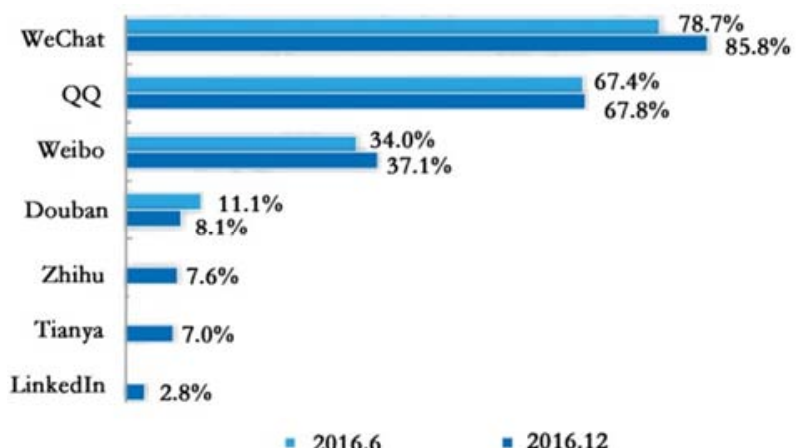

Figure 2. The usage rate of we-media in china (2016.6-2016.12) [6].

"The way in which information is generated and communicated is greatly changed in we-media era [7]", which is because its strong interactivity bringing a lot of convenience to facilitate users to the disseminating and sharing information, so each person could release news whenever and wherever possible. With many new experiences, we-media makes exchanges become more flexible and diverse, but it also bring many negative effects at the same time such as more and more false news and spam which is decided by the transmission characteristics of we-media.

Firstly, the amount of information released every time through we-media is relatively fewer than traditional media, low capacity information is difficult to express full details of the event comprehensively and objectively. We-media is often express an aspect of a thing or event which is hard to form full understanding of the objective truth, and easy to form misunderstanding or breed false news. Secondly, although the real name system has been implemented, users still have great information freedom in the world of we-media, lots of people tend to release irritating information in order to attract the 
attention of internet users to obtain a higher click rate. Sometimes they just intercept the most eye-catching part even quote out of context and without confirmation. Finally, there are significant individual characteristics with we-media, "traditional news production and communication methods are broken and personalized reading develops rapidly [8]", most of the content is not describing an event or thing simply but expressing the publisher's feelings, the emotions attached to the expression of events is easily spread in Internet users which could cause irrational emotions.

"The rise of we-media has greatly increased the fragmentation of information [9]", and the use of language in we-media communication showing a obvious fragmentation characteristics, because of the limit of length and the propagation characteristics, expression of we-media can not reflect the fact fully and comprehensively, what people see is usually a piece or segment of the fact with the publisher's subjective tendency. At the same time, the style of language will be scattered, more and more sentence which do not comply with the syntax specification become a popular trend. "At the same time, due to the grassroots and low threshold, language violence began on the Internet, and became a lethal tool that greatly affects the social stability [10]", So there is a fear that a new generation of children grown up with we-media will too lazy to think and use words carefully, in that case, the traditional culture is easy to form fault. Characteristic of fragmentation has become a recognized defect of we-media language and how to regulate it is an urgent task.

\section{The Reference Value of General Semantics to We-Media Language}

The theory of general semantics shows that "human form a judgment and evaluation of the world after the neural psychological process, the judgment and evaluation lead to the behaviors called thinking, communication, conversation, decision, conclusion, explanation, description, and so on. Language provides the means and environment which the evaluation process could occur and conduct, and the way to use language determines people's evaluation methods and the relationship between people with their own, and others, and around the world [11]". We-media has become a part of people's life and its language has become the means of us to describe non linguistic world. Since the fragmentation characteristics of we-media language will cause some negative impacts, it is an urgent task to overcome this influence and create a more objective and pure language environment, scientific composition of general semantics theory just can be used as reference.

It is an important goal to reduce misunderstandings and disputes between people of general semantics by using language correctly. Korzybski put forward an attitude of objective reality advocated "focus on facts rather than language [12]", which is basement of reflecting the objective reality correctly general semantics developed its theory system based on this target and attitude. In the process of integration, guidance methods of media language need to be more effective and scientific, now analyze language problems of we-media according to several basic principles of general semantics, and to seek how to make we-media language more standardized.

First of all, any people and things are not the same one with the passage of time according to general semantics, such as U. S. President Trump in November 9, 2016 is different from himself in November 8, 2016 because he was elected president of the United States. And general semantics indicates that identity cognition attitude would lead to deviation or mistake Judgment due to differences between things, which reminds we-media users to handle the relationship between language and reality in the view of development.

Secondly, the non full principle of general semantics refers to the objective reality is not completely consistent with its language expression, because the reality of objects is with infinite diversity which is changing constantly, but language is always limited which is not possible to express the features of reality fully. General semantics scholars advocate orienting extension, reminding to pay attention to those omitted features. This guide people pay more attention to expressions which are far away from the actual, never accept and spread information by we-media without thinking, in order to improve the ability and consciousness to identify one-sided and exaggeration language. If everyone is able to be more rational, the use of language will be more scientific in we-media communication.

Thirdly, general semantics indicated that language has an ability of self reflection, which could make a statement about another statement, the second statements is about the thirdly statement, and this is an infinitely cyclical process. In this case, the farther expression from the initial objective facts, the deviation is bigger, and the higher the level of abstraction of the concept, the degree of risk is greater in this process. The above analysis is very obvious in we-media, deviations of information are inevitable after forwarding and commenting. So communicator has to remain vigilant to abstract information, and pay attention to the accuracy degree of extension while using language in we-media.

General semantic analysis emphasizes the diversification and individuality of the objective things, respect for each user's personality in the world of we-media. It has a certain practical significance to establish a scientific awareness of using language, cultivate the habit of civilized expression, improve the ability to distinguish the false information.

\section{The Feasibility of the Application of General Semantic in We-Media}

General semantics has positive significance to solve the negative impact caused by the fragmentation features of we-media language, but there still exist great difficulties to apply semantics theory widely in we-media communication. There are certain doubts with the feasibility of the application of general semantic in we-media because of the complexity of general semantics, then analyze the problem by compare two 
pairs of contradictions between general semantics theory and we-media communication.

Firstly, there is a contradiction between the pursuit of scientific and rational of general semantics and the emotional appeal of we-media. General semantics scholars believe that "the most rational language is that of science, such as $2 \times 2=4,100^{\circ} \mathrm{C}$, understanding of these words will be consistent no matter senator, Catholic, worker, capitalist [13]". They pursue science language which is able to take pictures of reality, vague and abstract representation is not allowed. But as a personalized expression tool, lengthy reports and theoretical language is not suitable to we-media, the expression of life and feeling with certain emotions is better. General semantics ignore the fuzziness of language, and its just the origin of poetic, aesthetic feeling and expressiveness to a certain extent. In pursuit of science, general semantics has harmed poetry to a certain extent, however, this does not prevent the improvement of the vividness of language on the premise of exact expression.

Secondly, there is a contradiction between the semantic analysis and the simple characteristic of we-media language. General semantics scholars pointed out abstract process while language reflecting things is the main reason lead to misunderstanding, they presented five ways of expressing to limit the extension of things such as adding "etc." after words, coding for words, adding date tagging, adding conjunction operator and adding quotes. For example, what "Trump 2016.11.9" and "Trump 2016.11.1" used is the method of adding date tagging. These methods can make the use of language more accurate but it is not consistent with people's free and easy habits of we-media.

\section{Conclusion}

To sum up, there are still some unscientific factors which can't be a theoretical tool to guide the practice, at the same time, the contradictions between general semantics theory and practical use of we-media language determined it is difficult to apply the semantic analysis to we-media communication. But it is undeniable that general semantics has reference significance to create a more orderly media environment. "The development of the media industry often begins with technological changes [14]", in this context, we-media language is an important tool for people to communicate rather than a source of misunderstandings and disputes. "As the influence grows, the social responsibility of we-media should also be highly concerned [15]", the form of we-media has been developing continuously, language, pictures, video and other forms of media are more closely related, it also needs to improve the scientific level of language applications. So although there is a certain degree of difficulty to apply the scientific part of general semantics theory to practice, communicator still need to take its essence, to its dregs, optimizing the language of we-media communication with general semantics creatively.

\section{Acknowledgements}

This paper is supported by shanghai philosophical and social science foundation project "Communication strategy of shanghai regional culture based on mobile Internet" (2016EXW001).

\section{References}

[1] Wenjuan Tong, "The Influence of We Chat on News Communication", Journalism Communication, April 2017, Page 91.

[2] Safran-Tanca, Qiaojie Chen, "general semantics and news writing", "The press", January 1986, Page 31.

[3] Guoliang Zhang, "Classical text of communication", Fudan University press, 2006, Page 255-258.

[4] Jin Wen, "The competitive landscape and the future of We-media”, Audio-visual industry, February 2017, Page 61.

[5] CNNIC, "the 39th China Internet development status survey report”, [EB/OL]. (2017-01-22).

http://www.cnnic.cn/gywm/xwzX/rdxw/20172017/201701/t20 170122_66448.htm.

[6] CNNIC, "the 39th China Internet development status survey report", [EB/OL]. (2017-01-22).

http://www.cnnic.cn/gywm/xwZx/rdxw/20172017/201701/t20 170122_66448.htm.

[7] Yutao Jia, "Network public opinion collection and guidance in New media age", New Media Research, March 2017, Page 7.

[8] Zhenhui Li, "Information diffusion and content generation", Modern communication, March 2017, Page 160.

[9] Liwei Zhang, "From depth reports to integrated reports", Shanghai journalism review, July2016, Page 43.

[10] Yubo Hou, "The motive and influence of Chinese netizens' online violence", Journal of Peking University, January2017, Page 101.

[11] About General Semantics [EB/OL]. (2006-03-12). $\mathrm{http} / / /$ www.general semantics.org/about/aboutgs $2 . \mathrm{htm}$.

[12] S. I. Hayakawa, "Semantics, law and a man of a kind heart", "etc", October 1962.

[13] Guoliang Zhang, "Classical text of communication", Fudan University press, 2006, Page260.

[14] Bing Tong, "Reconstruction of Government Emergency Communication System In the context of the Internet", Contemporary communication, February 2017, Page 4.

[15] Ying Zhong, "The practice and status of new media social responsibility", University of news, January2017, Page 62. 